\title{
Follow-up Study of Continuation versus Discontinuation of Home Exercise in Type 2 Diabetes Patients
}

\author{
TAKUYA TAMURA ${ }^{1,2)}$, KAZUYUKI KIDA ${ }^{1)}$, FUTOSHI SUETSUNA ${ }^{2,3)}$, \\ NOBUHIKO KASAI ${ }^{4)}$, TAKAKO SEKI ${ }^{5)}$ \\ 1) Department of Health Promotion, Division of Health Sciences, Hirosaki University Graduate School \\ of Health Sciences \\ 2) Department of Rehabilitation, Hachinohe City Hospital: 1 Tamukai Bishamontaira, Hachinohe city, \\ Aomori 031-8555 Japan. TEL: +81 178-72-5111, FAX: +81 178-72-5115, \\ E-mail: ttstage2000@yahoo.co.jp \\ 3) Department of Orthopedics, Hirosaki University School of Medicine \\ 4) Department of Endocrinology and Diabetes, Hachinohe City Hospital \\ ${ }^{5)}$ Department of Physical Therapy, Tohoku Medical College
}

\begin{abstract}
Purpose] The purposes of the present study were to understand and to analyze the current situation, including lifestyle and environmental factors, of type 2 diabetes patients receiving treatment, in order to identify factors facilitating the continuation of exercise therapy and thereby determine the optimal focus of care instructions. [Methods] The subjects were patients with type 2 diabetes admitted to Hachinohe City Hospital for instructional purposes, for whom individual exercise therapies were prescribed. All the subjects were discharged from the hospital 3 years or more before participating in the study. The subjects were asked via telephone interview whether they were still exercising after discharge from hospital. Based on the results of the telephone survey, a univariate analysis (bivariate logistic regression analysis of parameters affecting the continuation or discontinuation of exercise) was performed to determine the significance of each parameter. [Results] The following factors were identified as facilitating the continuation of exercise therapy: 1) goal setting, 2) absence of impeding factors, 3) operant conditioning, 4) self-monitoring, 5) presence of someone providing instruction on how to exercise, 6) confidence in exercising even when busy doing household duties or working, 7) suffering no disadvantage from exercising, 8) use of exercise facilities and 9) age (advanced age was associated with a higher continuation rate). [Conclusion] To our knowledge, no previous study has focused on which instruction method is optimal based on follow-up survey results. Targeted care instruction can be provided by statistically analyzing differences between patients who continue exercising and those who do not and incorporating the results of the analysis into exercise instruction.
\end{abstract}

Key words: Diabetes mellitus, Exercise therapy, Follow-up survey

(This article was submitted Jun. 11, 2010, and was accepted Jul. 31, 2010)

\section{INTRODUCTION}

The Japanese Certification Board for Diabetes Educator has reported that the exercise continuation rate among Japanese type 2 diabetes patients is very low, ranging from $40 \%$ to $60 \%$. Nevertheless, no study has aimed at establishing guidelines for promoting the continuation of exercise therapy. In several countries other than Japan, community health centers are utilized to promote the continuation of exercise therapy by diabetic patients ${ }^{1,2)}$. On the other hand, in Japan, diabetes exercise therapy is performed at medical institutions. In addition, the fee for diabetes exercise therapy is included in the basic medical fee and cannot be calculated as a separate medical treatment fee. These background factors appear to preclude improvements in exercise instruction for Japanese diabetic patients. At Hachinohe City Hospital, physical therapists have actively been involved in diabetes exercise therapy. In our previous study, designed to examine the effectiveness of an intervention by physical therapists in diabetes exercise therapy, we interviewed a total of 101 patients with type 2 diabetes to assess the exercise therapy continuation rate 1 year after the prescription of the therapy. We performed a telephone interview with patients who had been prescribed step exercise, which can be done even in winter, and confirmed that $88 \%$ of these patients were still exercising throughout the year. The most common types of continuously performed exercises were walking and the step exercise. Most of the patients who maintained their exercise regimen showed good glycemic control while most of those 
patients who had ceased exercising had poor glycemic control. These findings suggest that prescribing exercise therapy at an appropriate intensity that can be performed indoors, even when there is snow outside, results in a high exercise continuation rate. The present study was designed to identify lifestyle and environmental factors affecting patients who continued to exercise after discharge from the hospital and those who did not, to clarify the differences between these two groups of patients, and thereby establish a new instruction method based on lifestyle and environmental factors.

\section{SUBJECTS AND METHODS}

\section{Subjects}

The subjects were patients with type 2 diabetes who were admitted to Hachinohe City Hospital for instructional purposes, for whom individual exercise therapies were prescribed. All the subjects were discharged from the hospital 3 years or more before participating in the study.

Detailed information about the subjects is shown in Table 1. There were 49 men and 38 women. The men had a mean age of $49.4 \pm 12.8$ years, mean height of $168.5 \pm 8.1 \mathrm{~cm}$, mean body weight of $70.7 \pm 18.0 \mathrm{Kg}$ and mean body mass index (BMI) of $24.3 \pm 5.3$. Their mean HbAlc level as a measure of glycemic control was $10.7 \pm 2.2 \%$ at the time of physical therapy (PT) prescription, $6.91 .4 \%$ at 1 year postdischarge and $7.7 \pm 2.0 \%$ at 3 years post-discharge.

The women had a mean age of $54.1 \pm 15.0$ years, mean height of $153.4 \pm 7.1 \mathrm{~cm}$, mean body weight of $62.4 \pm 16.0$ $\mathrm{Kg}$ and mean BMI of $26.5 \pm 7.0$. Their mean HbA1c level as a measure of glycemic control was $10.1 \pm 1.7 \%$ at the time of PT prescription, $7.5 \pm 1.5 \%$ at 1 year post-discharge and $8.1 \pm 1.6 \%$ at 3 years post-discharge. Details of medications prescribed to both men and women are also shown in the table.

\section{Methods}

Informed consent was obtained from each subject by sending an informed consent document by mail. Subsequently, a telephone interview was carried out.

1) Objective evaluation of the status of continuation: Interviewers asked about the subjects' daily activities and objectively determined whether exercise therapy had been continued or discontinued.

2) Evaluation of factors contributing to the success or failure (including lack of full compliance with the prescribed regimen) of exercise continuation during the maintenance period:

Patients items associated with success or failure of exercise continuation during the maintenance period were surveyed by telephone interview. Specific survey items were adapted from "A study on the development and utilization of teaching materials based on behavioral scientific approaches for the acquisition and continuation of exercise habits", a general health science research project sponsored by a grant-in-aid for scientific research provided by the Ministry of Health, Labour and Welfare.

After completion of steps 1) and 2) above, multivariate
Table 1. Physique $\cdot$ Pharmacotherapy $\cdot \mathrm{HbA} 1 \mathrm{c}$

\begin{tabular}{lcc}
\hline & Men $(\mathrm{n}=49)$ & Women $(\mathrm{n}=38)$ \\
\hline Anthropometrics & & \\
Age (years) & $49.4 \pm 12.8$ & $54.1 \pm 15.0$ \\
Height (cm) & $168.5 \pm 8.1$ & $153.4 \pm 7.1$ \\
BMI & $70.7 \pm 18.0$ & $62.4 \pm 16.0$ \\
\hline Medication & $24.8 \pm 5.3$ & $26.5 \pm 7.0$ \\
(oral hypoglycemic agents) & & \\
Medication(-) & 5 & 1 \\
Medication(+) & 36 & 29 \\
Insulin & 4 & 1 \\
Medication and insulin & 4 & 7 \\
\hline HbA1c & & \\
At start of PT (\%) & $10.7 \pm 2.2$ & $10.1 \pm 1.7$ \\
1 year post-discharge (\%) & $6.9 \pm 1.4$ & $7.5 \pm 1.5$ \\
3 years post-discharge (\%) & $7.7 \pm 2.0$ & $8.1 \pm 1.6$ \\
\hline
\end{tabular}

analysis was performed to statistically determine factors affecting the continuation and discontinuation of exercise. Statistical analyses were performed to identify factors facilitating and impeding the continuation of exercise. The method of instruction, i.e. how to exercise, was then devised based on the analysis results. The details of the survey items used in the present study were not described in the informed consent document sent to the subjects, as there was concern that thse subjects might give biased responses if they were provided with such information. As a first step, univariate analysis was performed to test the significance of each parameter. Then, in the second step, only the significant parameters were subjected to logistic regression analysis for determination of the significance of differences.

\section{RESULTS}

The informed consent document was sent by mail to 101 subjects who were involved in the previous study. Eightyseven of them agreed to participate in the present study and were then interviewed by telephone as described above. The results of the univariate analysis to determine the significance of each parameter are summarized in Table 2. The subsequent logistic regression analysis identified the following factors as facilitating the continuation of exercise therapy (Table 3):

1) goal setting $(\mathrm{P}=0.000), 2)$ absence of impeding factors $(\mathrm{P}=0.000), 3)$ operant conditioning $(\mathrm{P}=0.000), 4)$ selfmonitoring $(\mathrm{P}=0.002), 5)$ presence of someone providing instruction on how to exercise $(\mathrm{P}=0.002), 6)$ confidence in exercising even when busy doing household duties or working $(\mathrm{P}=0.003), 7)$ suffering no disadvantage from exercising $(\mathrm{P}=0.003), 8)$ use of exercise facilities $(\mathrm{P}=$ $0.025)$ and 9 ) age (advanced age was associated with a higher continuation rate) $(\mathrm{P}=0.039)$. These 9 factors were statistically significant according to the analysis of psychological, behavioral and environmental factors 3 years after hospital discharge, although age was shown to be an invariable factor (probably because older subjects were less 
Table 2. Results of univariate analysis

\begin{tabular}{|c|c|c|c|c|c|c|c|c|c|}
\hline & & Continuation & Discontinuation & Total & & & Continua & ntinuation & Total \\
\hline Age & $\begin{array}{l}\text { Mean } \\
\text { SE }\end{array}$ & $\begin{array}{l}52.62 \\
1.505\end{array}$ & $\begin{array}{c}42.6 \\
5.319\end{array}$ & & $\begin{array}{l}\text { Presence of someone aware } \\
\text { of the goal }\end{array}$ & $\begin{array}{l}\text { Yes } \\
\text { No }\end{array}$ & $\begin{array}{c}70 \\
7 \\
\end{array}$ & $\begin{array}{l}7 \\
3 \\
\end{array}$ & $\begin{array}{l}77 \\
10\end{array}$ \\
\hline Gender & $\begin{array}{l}\text { Male } \\
\text { Female }\end{array}$ & $\begin{array}{l}43 \\
34\end{array}$ & $\begin{array}{l}6 \\
4\end{array}$ & $\begin{array}{l}49 \\
38\end{array}$ & $\begin{array}{l}\text { Presence of someone } \\
\text { to talk with }\end{array}$ & $\begin{array}{l}\text { Yes } \\
\text { No }\end{array}$ & $\begin{array}{l}66 \\
11 \\
\end{array}$ & $\begin{array}{l}7 \\
3 \\
\end{array}$ & $\begin{array}{l}73 \\
14 \\
\end{array}$ \\
\hline \multirow{2}{*}{$\begin{array}{l}\text { Knowledge about exercise } \\
\text { (exercise intensity) }\end{array}$} & \multirow{2}{*}{$\begin{array}{l}\text { Yes } \\
\text { No }\end{array}$} & \multirow{2}{*}{$\begin{array}{c}76 \\
1 \\
\end{array}$} & \multirow{2}{*}{$\begin{array}{c}10 \\
0\end{array}$} & \multirow{2}{*}{$\begin{array}{c}86 \\
1 \\
\end{array}$} & $\begin{array}{l}\text { Presence of someone the subject } \\
\text { can invite to exercise together }\end{array}$ & $\begin{array}{l}\text { Yes } \\
\text { No }\end{array}$ & $\begin{array}{c}68 \\
9\end{array}$ & $\begin{array}{l}7 \\
3\end{array}$ & $\begin{array}{l}75 \\
12\end{array}$ \\
\hline & & & & & $\begin{array}{l}\text { Presence of someone inviting } \\
\text { the subject to exercise together }\end{array}$ & $\begin{array}{l}\text { Yes } \\
\text { No }\end{array}$ & $\begin{array}{c}68 \\
9\end{array}$ & $\begin{array}{l}8 \\
2 \\
\end{array}$ & $\begin{array}{l}76 \\
11 \\
\end{array}$ \\
\hline $\begin{array}{l}\text { Knowledge about exercise } \\
\text { (exercise type) }\end{array}$ & Yes & 77 & 10 & 87 & \multirow{2}{*}{$\begin{array}{l}\text { Presence of someone providing } \\
\text { instruction on how to exercise }\end{array}$} & \multirow{2}{*}{$\begin{array}{l}\text { Yes } \\
\text { No }\end{array}$} & \multirow{2}{*}{$\begin{array}{l}67 \\
10\end{array}$} & \multirow{2}{*}{$\begin{array}{l}4 \\
6\end{array}$} & \multirow{2}{*}{$\begin{array}{l}71 \\
16 \\
\end{array}$} \\
\hline \multirow{2}{*}{$\begin{array}{l}\text { Daily amount of exercise is } \\
\text { sufficient }\end{array}$} & Yes & 63 & 0 & $\begin{array}{l}63 \\
24\end{array}$ & & & & & \\
\hline & No & 14 & 10 & & $\begin{array}{l}\text { Presence of someone who cares } \\
\text { about the subject }\end{array}$ & $\begin{array}{l}\text { Yes } \\
\text { No }\end{array}$ & $\begin{array}{c}74 \\
3\end{array}$ & $\begin{array}{l}8 \\
2\end{array}$ & $\begin{array}{c}02 \\
5\end{array}$ \\
\hline Goal setting & $\begin{array}{l}\text { Yes } \\
\text { No }\end{array}$ & $\begin{array}{c}75 \\
2 \\
\end{array}$ & $\begin{array}{l}5 \\
5 \\
\end{array}$ & $\begin{array}{c}80 \\
7 \\
\end{array}$ & $\begin{array}{l}\text { Presence of someone } \\
\text { critical of the subject }\end{array}$ & No & 77 & 10 & 87 \\
\hline $\begin{array}{l}\text { Knowing the locations } \\
\text { of exercise facilities }\end{array}$ & $\begin{array}{l}\text { Yes } \\
\text { No }\end{array}$ & $\begin{array}{c}69 \\
8\end{array}$ & $\begin{array}{l}7 \\
3\end{array}$ & $\begin{array}{l}76 \\
11\end{array}$ & $\begin{array}{l}\text { Confidence in exercising } \\
\text { even in hot summer weather }\end{array}$ & $\begin{array}{l}1 \\
2\end{array}$ & $\begin{array}{c}11 \\
0\end{array}$ & $\begin{array}{l}3 \\
7\end{array}$ & $\begin{array}{c}14 \\
7\end{array}$ \\
\hline Use of exercise facilities & $\begin{array}{l}\text { Yes } \\
\text { No }\end{array}$ & $\begin{array}{l}53 \\
24\end{array}$ & $\begin{array}{l}3 \\
7\end{array}$ & $\begin{array}{l}56 \\
31\end{array}$ & indicates higher confidence) & $\begin{array}{l}3 \\
4 \\
5\end{array}$ & $\begin{array}{l}36 \\
18 \\
12\end{array}$ & $\begin{array}{l}0 \\
0 \\
0\end{array}$ & $\begin{array}{l}36 \\
18 \\
12\end{array}$ \\
\hline Self-monitoring & $\begin{array}{l}\text { Yes } \\
\text { No }\end{array}$ & $\begin{array}{l}66 \\
11\end{array}$ & $\begin{array}{l}4 \\
6 \\
\end{array}$ & $\begin{array}{l}70 \\
17 \\
\end{array}$ & $\begin{array}{l}\text { Confidence in exercising } \\
\text { even in cold winter weather } \\
\text { (a larger number indicates }\end{array}$ & $\begin{array}{l}1 \\
2 \\
3\end{array}$ & $\begin{array}{c}13 \\
0 \\
58\end{array}$ & $\begin{array}{l}6 \\
4 \\
0\end{array}$ & $\begin{array}{c}19 \\
4 \\
58\end{array}$ \\
\hline Benefiting from exercise & Yes & 77 & 10 & 87 & higher confidence) & $\begin{array}{l}4 \\
5\end{array}$ & $\begin{array}{l}2 \\
4\end{array}$ & $\begin{array}{l}0 \\
0\end{array}$ & $\begin{array}{l}2 \\
4\end{array}$ \\
\hline $\begin{array}{l}\text { Suffering a disadvantage } \\
\text { from exercise }\end{array}$ & $\begin{array}{l}\text { Yes } \\
\text { No }\end{array}$ & $\begin{array}{l}16 \\
61\end{array}$ & $\begin{array}{l}7 \\
3\end{array}$ & $\begin{array}{l}23 \\
64\end{array}$ & $\begin{array}{l}\text { Confidence in exercising } \\
\text { even when it is raining }\end{array}$ & 1 & $\begin{array}{c}13 \\
2\end{array}$ & $\begin{array}{l}7 \\
3\end{array}$ & $\begin{array}{c}20 \\
5\end{array}$ \\
\hline $\begin{array}{l}\text { Presence of factors } \\
\text { impeding exercise }\end{array}$ & $\begin{array}{l}\text { Yes } \\
\text { No }\end{array}$ & $\begin{array}{c}6 \\
71\end{array}$ & $\begin{array}{l}9 \\
1\end{array}$ & $\begin{array}{l}15 \\
72\end{array}$ & higher confidence) & $\begin{array}{l}4 \\
5 \\
\end{array}$ & $\begin{array}{l}1 \\
3 \\
\end{array}$ & $\begin{array}{l}0 \\
0 \\
0\end{array}$ & $\begin{array}{l}1 \\
3 \\
\end{array}$ \\
\hline $\begin{array}{l}\text { Stimulation control } \\
\text { method }\end{array}$ & $\begin{array}{l}\text { Yes } \\
\text { No }\end{array}$ & $\begin{array}{c}77 \\
0\end{array}$ & $\begin{array}{l}4 \\
6\end{array}$ & $\begin{array}{c}81 \\
6\end{array}$ & $\begin{array}{l}\text { Confidence in exercising } \\
\text { even when busy doing } \\
\text { household duties or working }\end{array}$ & $\begin{array}{l}1 \\
2 \\
3\end{array}$ & $\begin{array}{c}15 \\
2 \\
34\end{array}$ & $\begin{array}{l}2 \\
7 \\
1\end{array}$ & $\begin{array}{c}17 \\
9 \\
35\end{array}$ \\
\hline Operant conditioning & Yes & 72 & 2 & 74 & higher confidence) & $\begin{array}{l}4 \\
5\end{array}$ & $\begin{array}{c}5 \\
21\end{array}$ & $\begin{array}{l}0 \\
0\end{array}$ & $\begin{array}{c}5 \\
21\end{array}$ \\
\hline & No & 5 & 8 & & $\begin{array}{l}\text { Change(s) in living } \\
\text { environment }\end{array}$ & $\begin{array}{l}\text { Yes } \\
\text { No }\end{array}$ & $\begin{array}{c}72 \\
5\end{array}$ & $\begin{array}{l}9 \\
1\end{array}$ & $\begin{array}{c}81 \\
6\end{array}$ \\
\hline & & & & & $\begin{array}{l}\text { Change(s) in diabetes } \\
\text { treatment regimen }\end{array}$ & $\begin{array}{l}\text { Yes } \\
\text { No }\end{array}$ & $\begin{array}{c}69 \\
8\end{array}$ & $\begin{array}{l}9 \\
1\end{array}$ & $\begin{array}{c}78 \\
9\end{array}$ \\
\hline
\end{tabular}

likely to have jobs and thus had more time to exercise than younger subjects). Thus, it was statistically confirmed that those meeting criteria 1) to 8) above after hospital discharge were more likely to continue exercise than those who did not.

Meanwhile, the results of the analysis of psychological, behavioral and environmental factors revealed that the following 14 factors did not affect the continuation or discontinuation of exercise in type 2 diabetes patients: 1) gender, 2) knowledge about exercise, 3) knowing the locations of exercise facilities, 4) stimulation control method, 5) being aware of the goal, 6) presence of someone to talk with, 7) presence of someone the subject can invite to exercise together, 8) presence of someone inviting the subject to exercise together, 9) presence of someone who cares about the subject, 10) confidence in exercising even in summer, 11) confidence in exercising even in winter, 12) confidence in exercising even when it is raining, 13) change(s) in the living environment and 14) change(s) in the diabetes treatment regimen.

\section{DISCUSSION}

One guideline recommends that diabetes be diagnosed based on a comprehensive assessment of the presence of chronic hyperglycemia, symptoms, clinical findings, family history, body weight change and other evidence ${ }^{3)}$. Diagnostic criteria for diabetes have been changed over time. While the WHO guideline is basically followed, various criteria are reviewed and proposed in different countries by such organizations like the Diabetes Diagnosis Criteria Review Committee. Type 2 diabetes is caused by interactions between genetic and acquired factors, such as overeating and insufficient exercise, and is characterized by hyperglycemia due to relative insulin insufficiency and insulin resistance. According to the current Japanese diagnostic criteria for diabetes, a patient is diagnosed as "diabetic type" if any of the following criteria are met: 1) early morning fasting blood glucose level of $126 \mathrm{mg} / \mathrm{dl}$ or more, 2) non-fasting blood glucose level of $200 \mathrm{mg} / \mathrm{dl}$ or more, and 3) 2-hour glucose level during oral glucose tolerance test of $200 \mathrm{mg} / \mathrm{dl}$ or more. Patients diagnosed as "diabetic type" on two different testing days are then diagnosed as having "diabetes". In addition, a patient diagnosed as "diabetic type" can be confirmed to have diabetes based on a single test if any of the following criteria are met: 1) presence of a typical symptom of diabetes (e.g. thirst, polydipsia, polyuria and weight loss), 2) HbA1c 
Table 3. Results of logistic regression analysis

\begin{tabular}{|c|c|c|c|c|}
\hline & & Odds ratio & & \\
\hline Age & & 1.049 & 1.002 & 1.098 \\
\hline Gender & & 0.843 & 0.220 & 3.229 \\
\hline $\begin{array}{l}\text { Knowledge about exercise } \\
\text { (exercise intensity) }\end{array}$ & & & & \\
\hline $\begin{array}{l}\text { Knowledge about exercise } \\
\text { (exercise type) }\end{array}$ & & & & \\
\hline $\begin{array}{l}\text { Daily amount of exercise is sufficient } \\
\text { Goal setting }\end{array}$ & & 37.500 & 5.762 & 244.068 \\
\hline Knowing the locations of exercise facilities & & 3.696 & 0.794 & 17.206 \\
\hline $\begin{array}{l}\text { Use of exercise facilities } \\
\text { Self-monitoring }\end{array}$ & & $\begin{array}{l}5.153 \\
9.000\end{array}$ & $\begin{array}{l}1.226 \\
2.182\end{array}$ & $\begin{array}{l}21.659 \\
37.124\end{array}$ \\
\hline Benefiting from exercise & & & & \\
\hline Suffering a disadvantage from exercise & & 0.112 & 0.026 & 0.484 \\
\hline Presence of factors impeding exercise & & 0.009 & 0.001 & 0.087 \\
\hline Stimulation control method & & & & \\
\hline Operant conditioning & & 57.600 & 9.568 & 346.773 \\
\hline Someone aware of the goal & & 4.286 & 0.901 & 20.391 \\
\hline Presence of someone to talk with & & 2.571 & 0.576 & 11.473 \\
\hline Presence of someone the subject can invite to exercise together & & 3.238 & 0.708 & 14.816 \\
\hline Presence of someone inviting the subject to exercise together & & 1.889 & 0.346 & 10.322 \\
\hline Presence of someone providing instruction in how to do exercise & & 10.050 & 2.407 & 41.955 \\
\hline Presence of someone who cares about the subject & & 6.167 & 0.893 & 42.578 \\
\hline Presence of someone critical of the subject & & & & \\
\hline $\begin{array}{l}\text { Confidence in exercising even in hot summer weather } \\
\text { (a larger number indicates higher confidence) }\end{array}$ & $\begin{array}{l}1 \\
2 \\
3 \\
4 \\
5\end{array}$ & & & \\
\hline $\begin{array}{l}\text { Confidence in exercising even in cold winter weather } \\
\text { (a larger number indicates higher confidence) }\end{array}$ & $\begin{array}{l}1 \\
2 \\
3 \\
4 \\
5\end{array}$ & & & \\
\hline $\begin{array}{l}\text { Confidence in exercising even when it is raining } \\
\text { (a larger number indicates higher confidence) }\end{array}$ & $\begin{array}{l}1 \\
2 \\
3 \\
4 \\
5\end{array}$ & 2.786 & 0.373 & 20.819 \\
\hline $\begin{array}{l}\text { Confidence in exercising even when busy doing household duties } \\
\text { or working (a larger number indicates higher confidence) }\end{array}$ & $\begin{array}{l}1 \\
2 \\
3 \\
4 \\
5\end{array}$ & 26.250 & 3.041 & 226.604 \\
\hline Change(s) in living environment & & 1.600 & 0.168 & 15.273 \\
\hline Change(s) in diabetes treatment regimen & & 0.958 & 0.107 & 8.579 \\
\hline
\end{tabular}


$\geq 6.5 \%$, and 3) presence of confirmed diabetic retinopathy. For patients who are diagnosed as having "diabetes" based on meeting the above diagnostic criteria, treatment regimens focusing on glycemic control will be initiated. One of the glycemic control measures used in the course of treatment is $\mathrm{HbA1c}$, which is also included in the diagnostic criteria. The HbA1c level varies in proportion to blood glucose levels during the period from the emergence of a red blood cell (carrying hemoglobin) to the time of measurement and thus reflects the mean blood glucose level during the prior 1 to 2 months. The lower and upper limits of the normal range of $\mathrm{HbA} 1 \mathrm{c}$ are $4.3 \%$ and $5.8 \%$, respectively, which are used as references for $\mathrm{HbA} 1 \mathrm{c}$ evaluation. More specifically, $\mathrm{HbA} 1 \mathrm{c}$ values of $<5.8 \%$ are classified as "excellent", $5.8 \%$ to $<6.5 \%$ as "good", $6.5 \%$ to $<8.0 \%$ as "fair" and $\geq 8.0 \%$ as "poor". The goal of diabetes treatment is to control the $\mathrm{HbA} 1 \mathrm{c}$ level to a maximum of $6.5 \%$, which is based on the finding of the Kumamoto Study ${ }^{4)}$ that patients with $\mathrm{HbA1c}$ levels below $6.5 \%$ and 2 -hour postprandial blood glucose below $180 \mathrm{mg} / \mathrm{dl}$ have a lower risk of developing capillary complications $^{5)}$.

Treatment regimens for type 2 diabetes patients have been assessed in large-scale studies conducted in different countries, including the 1) Diabetes Control and Complications Trial (DCCT) ${ }^{6}$, conducted with 1,441 patients between 1983 and 1993, which demonstrated that better glycemic control is effective for preventing complications; 2) Epidemiology of Diabetes Interventions and Complications (EDIC) ${ }^{7)}$, conducted with 1,375 patients between 1994 and present, which demonstrated that maintenance of good glycemic control for a certain period of time is followed by a prolonged treatment effect (based on examining the incidences of capillary complications and cardiovascular diseases); 3) Diabetes Prevention Program $(\mathrm{DPP})^{8)}$, conducted with 3,234 patients between 1996 and 1999, which demonstrated that lifestyle improvement is more effective than medication in preventing the development of diabetes; 4) Kumamoto Study ${ }^{4}$, conducted with 110 Japanese type 2 diabetes patients between 1987 and 1988, which demonstrated the rationale for glycemic control parameters; and 5) United Kingdom Prospective Diabetes Study (UKPDS)9), conducted with 4,297 patients between 1988 and 1997, which demonstrated that strict control of blood glucose levels and blood pressure prevents complications in not only type 1 but also type 2 diabetes patients.

Diabetes treatment regimens vary depending on the type and condition of diabetes and the degree of metabolic disturbance. For patients with non-insulin dependent type 2 diabetes, adequate diet and exercise therapies should be prescribed for 2-3 months. If good glycemic control is not obtained with these therapies, oral hypoglycemic agents and, eventually, insulin therapy should be prescribed. Type 2 diabetes patients who are pregnant, undergoing surgery requiring systemic management, or suffering from a serious infectious disease, should also be prescribed insulin therapy. Depending on the degree of metabolic disturbance, insulin and/or oral hypoglycemic agents, in addition to diet and exercise therapies, may be prescribed when treatment is initiated.

The effectiveness of exercise therapy as evidence-based medicine has been established by meta-analyses. In type 2 diabetic patients, decreased cardiopulmonary function and physical activity are considered to be related to cardiovascular manifestations and to mortality. A metaanalysis of studies examining the effects of exercise therapy on cardiopulmonary function in type 2 diabetes patients showed that exercising at an intensity of $50-75 \%$ of maximum oxygen uptake for about 50 minutes, 3-4 times weekly for 20 weeks, significantly increased maximum oxygen uptake ${ }^{10)}$. In addition, although type 2 diabetes patients often show insulin resistance, obesity, hypertension and abnormal lipid metabolism, exercise therapy can improve these abnormalities as well as glycemic control ${ }^{11)}$. A meta-analysis of studies employing exercise therapy over a period of 8 weeks or more showed that approximately 50 minutes of moderate-intensity exercise, 3-4 times weekly for 18 weeks, resulted in a significant $\mathrm{HbA} 1 \mathrm{c}$ improvement without weight loss ${ }^{12}$. More specifically, a study examining the insulin sensitivity improving effect of exercise ${ }^{13}$ ) demonstrated that the effect of a single exercise session continues for 2-3 days. A study examining the cumulative effect of exercise ${ }^{14)}$ demonstrated that repeated exercise increases the expression of glucose transporter (GLUT)-4, which transports glucose in response to signals from insulin and exercise (GLUT types 1 to 9 have been identified, to date).

The present study was designed to demonstrate the objectivity of the survey methods used for Japanese subjects to determine exercise continuation rates and, on the basis of these survey results, to statistically identify important factors that should be considered when prescribing exercise therapy. Previous studies did not examine the nature of differences observed between patients who continued exercise therapy and those who did not. The study methods were not standardized and only whether or not exercise was continued was examined. With the methods employed in the previous follow-up surveys, variable results can be obtained via subjective interpretations made by investigators. In the present study, to avoid such subjectivity, survey items were adapted from "A study on the development and utilization of teaching materials based on behavioral scientific approaches for the acquisition and continuation of exercise habits", a general health science research project sponsored by a grant-in-aid for scientific research provided by the Ministry of Health, Labour and Welfare. This study compared patients who continued exercise therapy and those who did not to identify differences between the two groups. In the present study, we selected objective, rather than subjective, qualitative questions and employed a comprehensive method.

In Japan, with the aim of improving the quality of medical professionals involved in diabetes care, the qualification system for certified diabetes educators has recently been established in a co-medical area. In view of this current trend, we believe the present findings to be of major significance. As mentioned above, we did not draw the usual conclusion that "such-and-such percent of patients 
continued exercise after discharge from the hospital and therefore exercise instruction is important". Instead, the present study statistically analyzed differences between patients who continued exercise and those who did not with the ultimate goal of incorporating the results of the analysis into exercise instruction, which we believe is the merit of the present study.

The only currently available finding regarding the continuation rate of exercise therapy in diabetes care is that exercise instruction increases the continuation rate. To the best of our knowledge, no previous study has focused on which instruction method is optimal based on follow-up survey results. We previously conducted a similar study in the past, but did not go into as much detail, such as analysis of patient demographics. What previous studies have shown is that there is no organization set up to follow diabetes exercise therapy and patients are left unattended once they are given exercise instruction. Previous studies have conducted follow-up surveys and simply determined the percentage of patients who continued exercise, but did not address solutions to qualitative problems. In this sense, the present study was able to scientifically elucidate what types of psychological, mental and environmental factors impact the continuation or discontinuation of exercise, allowing the results to be incorporated into the method of exercise instruction. The specific methods of instruction identified in the present study include 1) setting a clear goal, 2) identifying impeding factors and considering how to solve the problem, 3) starting operant conditioning during the teaching period, 4) making self-monitoring a habit, 5) providing instruction to someone able to teach the patient how to exercise (e.g. the patient's family members), 6) providing instruction allowing the patient to gain confidence in doing exercise even when he or she is busy doing household duties or working, 7) determining whether or not the patient suffers any disadvantage from exercise and discussing how to solve the problem, and 8) encouraging the patient to use nearby exercise facilities, if available.

While selected instruction methods were identified in the present study, no significant correlations were found between the exercise continuation rate and the following 14 factors: 1) gender, 2) knowledge about exercise, 3) knowing the locations of exercise facilities, 4) stimulation control method, 5) being aware of the goal, 6) presence of someone to talk with, 7) presence of someone the subject can invite to exercise together, 8) presence of someone inviting the subject to exercise together, 9) presence of someone who cares about the subject, 10) confidence in exercising even in summer, 11) confidence in exercising even in winter, 12) confidence in exercising even when it is raining, 13) change(s) in living environment and 14) change(s) in the diabetes treatment regimen. These factors were not statistically significant in the present study, but are still considered important in diabetes care. However, the present results were utilized in the development of a new instruction method focused on the 8 aforementioned factors found to be particularly important contributors to the continuation of exercise, rather than the above 14 factors. We consider it useful to identify particularly important instruction items and to provide appropriate instruction to patients within the limited time available during inpatient or outpatient instructional sessions on diabetes exercise therapy.

\section{REFERENCES}

1) Chin MH, Cook S, Jin L, et al.: Links barriers to providing diabetes care in community health centers. Diabetes Care, 2001, 24: 268-274.

2) Dunstan DW, Vulikh E, Owen N, et al.: Links Community center-based resistance training for the maintenance of glycemic control in adults with type 2 diabetes. Diabetes Care, 2006, 29: 2586-2591.

3) The expert committee on the diagnosis and classification of diabetes mellitus: Report of the expert committee on the diagnosis and classification of diabetes mellitus. Diabetes Care, 1997, 20: 1183-1197.

4) Shichiri M, Kishikawa H: Long-term results of the Kumamoto Study on optimal diabetes control in type2 diabetic patients. Diabetes Care, 2000, 23: B21-B29.

5) Ohkubo Y, Kishikawa H, Araki E,et al.: Intensive insulin therapy prevents the progression of diabetes mellitus: A randomized prospective 6-year study. Diabetes Res Clin Pract, 2000, 28: 225-230.

6) The diabetes control and complications trial research group: The effect of intensive treatment of diabetes on the development and progression of longterm complications in insulin-dependent diabetes mellitus. N Engl J Med, 1993, 329: 977-986.

7) The diabetes control and complications trial/epidemiology of diabetes interventions and complications research group: retinopathy and nephropathy in patients with type 1 diabetes four years after a trial of intensive therapy: $\mathrm{N}$ Engl J Med, 2000, 342: 381-389.

8) Knowler WC, Barrett-Connor E, Fowler SE, et al.: Diabetes prevention program research group: Reduction in the incidence of type 2 diabetes with lifestyle intervention or metformin: N Engl J Med, 2002, 346: 393-403.

9) United Kingdom Prospective Diabetes Study (UKPDS) Group. Intensive blood-glucose control with sulphonylureas or insulin compared with conventional treatment and risk of complications in patients with type 2 diabetes (UKPDS 33). Lancet, 1998, 352: 837-853.

10) Boulé NG, Kenny GP, Haddad E, et al.: Meta-analysis of the effect of structured exercise training on cardiorespiratory fitness in Type 2 diabetes mellitus.Diabetologia. Epub, 2003, 46: 1071-1081.

11) Alam S, Stolinski M, Pentecost C, et al.: The effect of a six-month exercise program on very low-density lipoprotein apolipoprotein B secretion in type 2 diabetes. J Clin Endocrinol Metab, 2004, 89: 688-694.

12) Boulé NG, Haddad E, Kenny GP, et al.: Effects of exercise on glycemic control and body mass in type 2 diabetes mellitus: a meta-analysis of controlled clinical trials. JAMA, 2001, 12: 1218-1227.

13) Devlin JT: Effects of exercise on insulin sensitivity in humans. Diabetes Care, 1992, 34: 1960-1693.

14) Etgen Jr GJ, Jensen J, Wilson CM, et al.: Exercise training reverses insulin resistance in muscle by enhanced recruitment of GLUT-4 to the cell surface. Am J Physiol Endocrinol Metab, 1997: E864-E869. 